\title{
FLOATING RAFT-PILE FOUNDATIONS ANALYSIS USING NUMERICAL SIMULATION
}

\author{
Helmy Darjanto ${ }^{1}$
}

\begin{abstract}
The numerical simulation of raft-pile foundations subjected to vertical load is presented in this paper. For comparison study, numerical models of single raft and pile groups are completed. The numerical models are adopting the elastic constitutive law for the materials. The stresses and vertical displacement of the models are observed. The behaviour of the raft-pile foundation compared to the pile-group is then investigated. The results using the same external load show that the raft-pile foundation has smallest displacement compared to the others. In terms of stresses, the raft shows contribution of the load transfer to the underneath soil as well as the piles. Moreover, the behaviour of the raft-pile system appears to be a combination of the pile-group and the single raft. In order to estimate the bearing capacity of the raft-pile system, it is suggested that the contribution of the raft should be included in addition of the piles'.
\end{abstract}

Keywords: raft-pile foundation, soil-structure interaction, floating foundation

\section{INTRODUCTION}

The total load of the pile groups involving the contribution of the cap using the numerical simulation has been purposed by (Valliappan, 1999). The pile groups including the effect of the cap transfer the load were then defined as the Raft-pile foundations. In this study, the raft-pile foundations are formed as a solid structure. Then the effects of each element forms the foundation can not be figured out. However in the practice, the group foundation is made of number of single piles which individually has a load capacity and a cap on the ground.

The proposed method for analyzing and designing the raft-pile system has been published (Davis, 1987). Indeed, the scheme for solving the problem is based on the analysis of the group of the piles rather than the behaviour of the system. Moreover, the proposed formulas are inadequate to be adopted for describing the behaviour of the system.

When a group of piles is made up of several individual piles, the load capacity of the group cap may not be the same as the sum of the load capacity piles. The effect of grouping the piles arises the different amount of the group capacity and the sum of the individual contributing piles in term of efficiency of the pile group. Based on the studies in the past, number of references have suggested the formulas to estimate the pile group efficiency (Das, 1990 and Boowles, 1988).

In practices, even the pile cap commonly poured directly on the ground and effect the load transfer mechanism, the effect of the cap to transfer the load to the underneath soil was usually unobserved. The contribution of the cap which plays the important roles to group the piles has not been studied well. Here, the effect of the cap of the pile groups is observed using numeral simulation. The term of raft-pile foundation is then adopted for describing the system of the foundation. 
A suggestion for the use of the virtual block capacity has been madein the past (Boowles, 1988). The analysis is based on the shear around the block plus the block bearing point instead of sum of the capacity of the piles. Then (Das, 1990) recommended adopting the lower values between those two amounts as the ultimate load of the group.

The effects of the piles and the cap in terms of stresses of soil underneath the foundation are studied here. The state of the art of the group efficiency formula employed to outline the load capacity is discussed. The formulas suggested by (Hakam, 2004) and (Hakam, 2005) for floating raft pile system in soft clays is then reviewed.

\section{LOAD CAPACITY OF RAFT-PILE SYSTEMS}

Based on several tests of foundations in laboratory (Hakam, 2004) analyzed the efficiency of the raft-pile foundation which is defined as ratio of the system compared to the sum of the individual pile and the raft. The efficiency of the raft-pile system, $\mathrm{E}_{\mathrm{rp}}$ is written as:

$$
E_{\mathrm{rp}}=\frac{\text { the raft - pile capacity }}{\text { the sum of individual pile and raft capacities }}
$$

Using the above equation, the efficiencies of the raft-pile system number of tests are found higher than $100 \%$.

Since the efficiency of the raft-pile system is greater than the sum of pile and raft capacities, it is suggested that for practical purposes to use the sum value of the piles and the raft that for load capacity purposes (Hakam, 2005). Afterward, for a raft-pile foundation floating in soft clay, the total load capacity of the system can be estimated as;

$$
\mathrm{Q}_{\mathrm{T}}=\mathrm{Q}_{\mathrm{R}}+\sum\left(\mathrm{Q}_{\mathrm{P}}+\mathrm{Q}_{\mathrm{S}}\right)
$$

Where $\mathrm{Q}_{\mathrm{R}}$ is the load capacity of the raft (in the pile group case, it is the cap), $\mathrm{Q}_{\mathrm{P}}$ and $\mathrm{Q}_{\mathrm{s}}$ are the bearing capacity of the pile at the tip and the skin resistance respectively.

The resistance of square raft foundation is thereafter predicted using the ultimate load capacity in the form;

$$
\mathrm{Q}_{\mathrm{R}}=\mathrm{A}_{\mathrm{b}} \mathrm{F}_{\mathrm{t}} \mathrm{Cu} \mathrm{N}{ }_{\mathrm{c}}^{*}
$$

Where, $A_{b}$ is the cross section area of the foundation at the base, the bearing capacity factor $\mathrm{N}_{c}{ }^{*}$ is 5,14 and the value of the type factor $F_{t}$ is 0.45 which represents the value for the punch failure. For strip foundations with length-width ratio equal or greater than one and a half, the ultimate load capacity $\mathrm{Q}_{\mathrm{u}}$ must be reduced by the factor of 0,77 .

The ultimate point bearing capacity of pile can be estimated using;

$$
\mathrm{Q}_{\mathrm{P}}=\mathrm{A}_{\mathrm{P}} \mathrm{Cu}_{(\mathrm{p})} \mathrm{N}_{\mathrm{c}}
$$

Where $\mathrm{Cu}_{(\mathrm{p})}$ is undrained cohesion soil strength at the pile tip, $\mathrm{A}_{\mathrm{P}}$ is the cross section area of the pile tip and $\mathrm{N}_{\mathrm{c}}$ is the bearing capacity factor, it is 9 for Meyerhof's and 5,7 for Janbu's one. However, since the piles are considered as floating one, the tip resistance will not be significant to contribute the pile capacity.

\section{0 | J URNAL REKAYASA SIPIL}


The skin resistance for pile with the perimeter, $\Theta$, is the sum of the resistance every length section, $\Delta \mathrm{L}$, that is calculated using;

$$
\mathrm{Q}_{\mathrm{S}}=\Sigma(\mathrm{Cu} \Theta \Delta \mathrm{L})
$$

\section{NUMERICAL SIMULATIONS AND RESULTS}

The numerical tool used in this simulation is the finite element method. The raft and the soil are modeled using three dimensional solid elements while the piles are modeled as beam elements. The vertical load set on the top of the raft is $20 \mathrm{ton} / \mathrm{m}^{2}$. The soil has the modulus of elasticity and Poisson's ratio of $20 \mathrm{~kg} / \mathrm{cm}^{2}$ and 0.4 respectively. For the raft and the piles that are $200000 \mathrm{~kg} / \mathrm{cm}^{2}$ and 0.2. The diameter of the piles is $10 \mathrm{~cm}$, the length of $150 \mathrm{~cm}$ and spacing of five times of the diameter. The raft is square in shape with the width of $100 \mathrm{~cm}$. The sketch of the simulation model and the boundaries are shown in the Figure 1. The results are presented in the form of stress contours and displacements in the following sections.

In the terms of vertical stresses for raft, pile group and raft-pile are shown in Figure 2,3 and $\mathbf{4}$ respectively. The colours of the contours are indicating the stress ratio compared to the total applied load of $20 \mathrm{t} / \mathrm{m}^{2}$ as follow: pink, red, brown, yellow, green and blue that are $-0.5,-0.3,-0.25$, $-0.15,-0.1$ and -0.01 . For shear stress contour (Figure 5 - 7), the same colours are indicating stress values of $-0.3,-0.1,-0.05,0.0,+0.05,+0.1$ and +0.3 respectively.

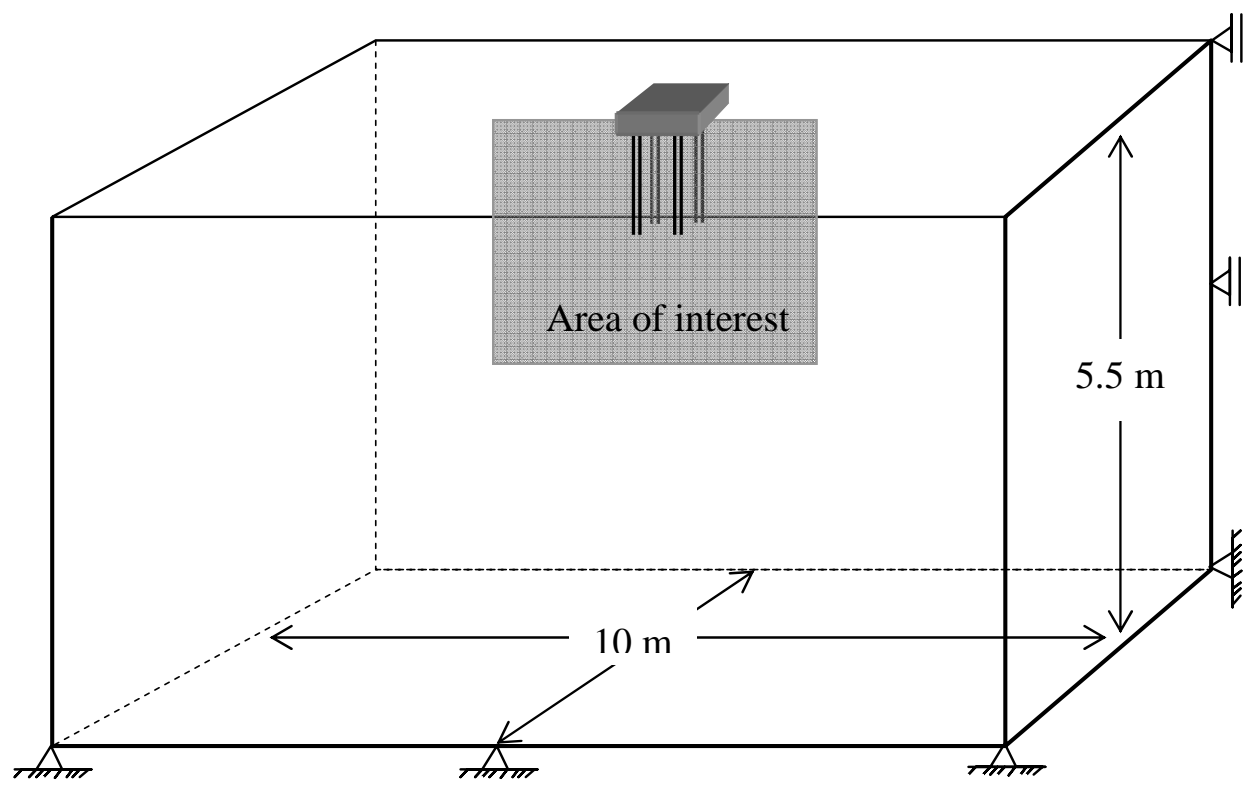

Figure 1. 3D Numerical Model 


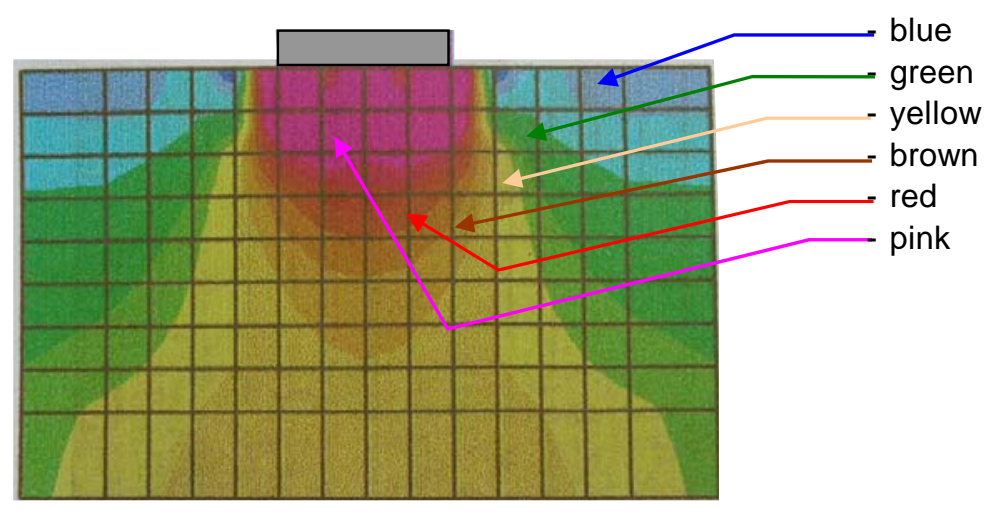

Figure 2. Vertical Stress of Raft Foundation

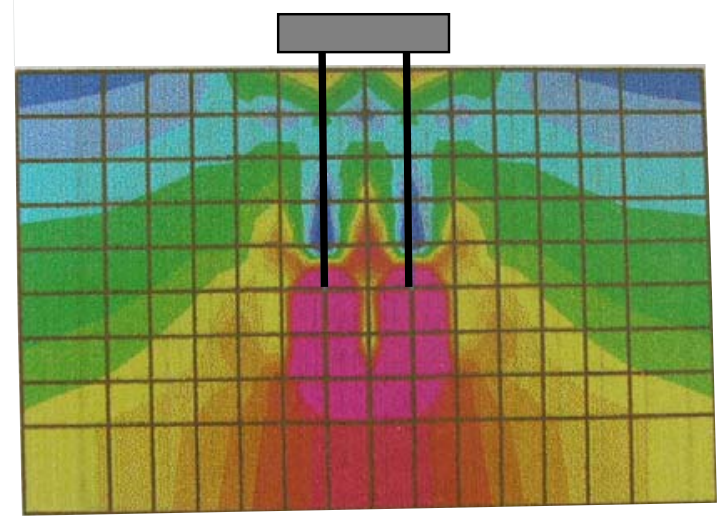

Figure 3. Vertical Stress of The Pile-Group

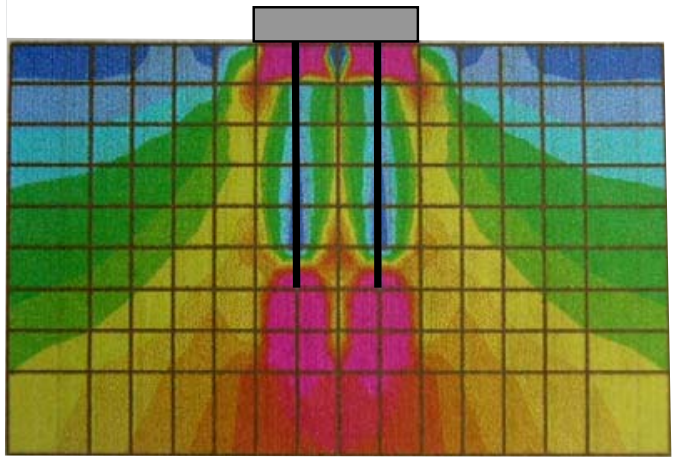

Figure 4. Vertical Stress of The Raft-Pile 
The normal stress in the soil for the single raft concentrates right under the base of the raft. Then it reduces gradually as it is away from the base (Figure 2). For the pile-group, the normal stress concentrates just around the tip of the piles, and reduces as it is far from. While, along the pile, the normal stress is not significant, it can be understood since in this area, the shear stress is dominant (Figure 3 and 6). For the raft-pile system, the compression in the soil is concentrate in two areas, right in the base of the raft and in the area around the piles' tip. Meanwhile along the pile between those area, the normal stress in reduces as it shown in the pile-group. It shows that the normal stress behaviour of the soil is combination between the raft and the piles (Figure 4). In the other words, the vertical load on the top of the raft-pile system is transferred in terms of normal stress to underneath soil under the base of the raft as well as under the tip of the piles.

Figure 5,6 and 7 show the shear stresses for raft, pile group and raft-pile under the foundation, respectively. The fart-pile foundation figure shows the deeper shear stress bulb compared to the others. It means that the soil deal with the shear stress covers up bigger area and then it gives greater value in term of load capacity.

Then, with the same vertical load applied on the top of the foundations, the maximum displacements of the foundation are presented in the Table 1.

The maximum displacement of each type of model gives the sensibly large values for practice. The reason is the vertical load on the top of foundation is large enough since the soil parameter performing the soft soil. However, the displacement of raft-pile gives the smallest value compared to the others. In the other word for the same displacement allowed, the raft-pile can restrain greater load than the others.

In fact, it is unrealistic to expect reliable good bearing capacity on soft soils. So, it is reasonable to take into account every element of the system that contributing to support external load. Then, the load capacity of the raft-pile must include the part of piles as well as the raft. Using combination of classic formulas, the procedures to estimate the load capacity as described in the beginning section is very worthy to be adopted. Furthermore, if the conventional load capacity formulas are considered, the efficiency of the raft-pile system must be defined as a ratio of the system compared to the sum of the individual pile and the raft.

Table 1. Maximum Displacement of Foundations

\begin{tabular}{|c|c|c||}
\hline Foundation type & Displacement $\mathbf{( c m )}$ & Ratio to pile-group \\
\hline Raft & 13.6 & $108 \%$ (8\% greater) \\
\hline Pile-group & 12.6 & $100 \%$ \\
\hline Raft-pile & 11.7 & $93 \%$ (7\% less) \\
\hline
\end{tabular}




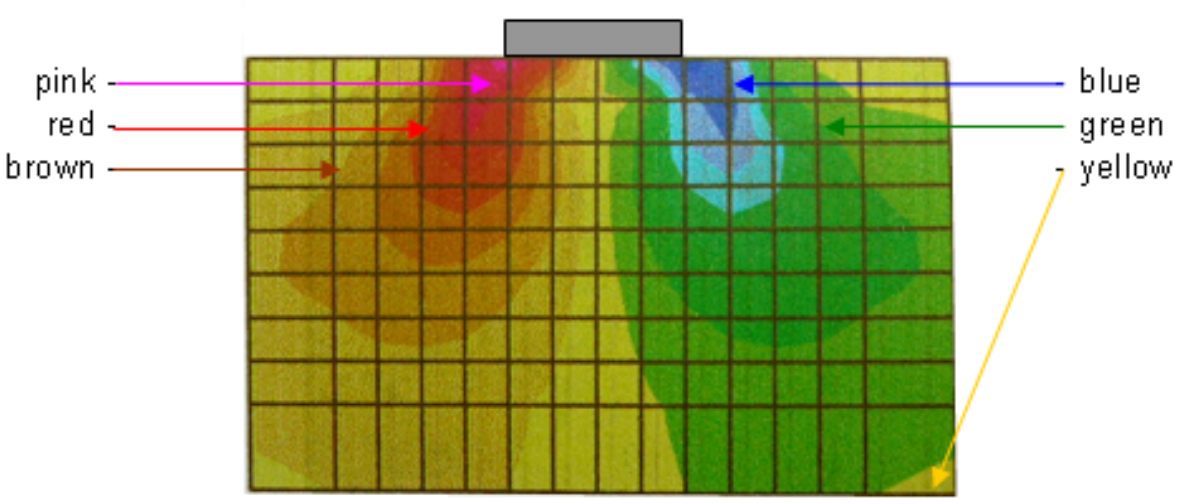

Figure 5. Shear Stress Under The Raft

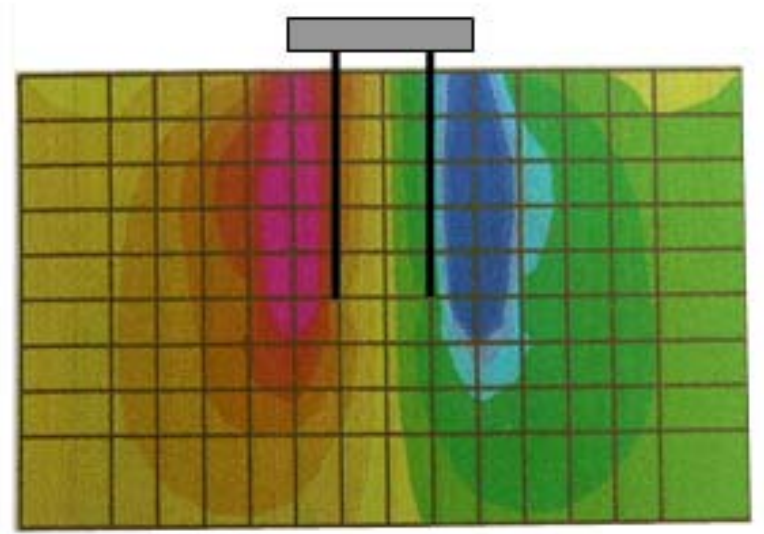

Figure 6. Shear Stress For The Pile-Group

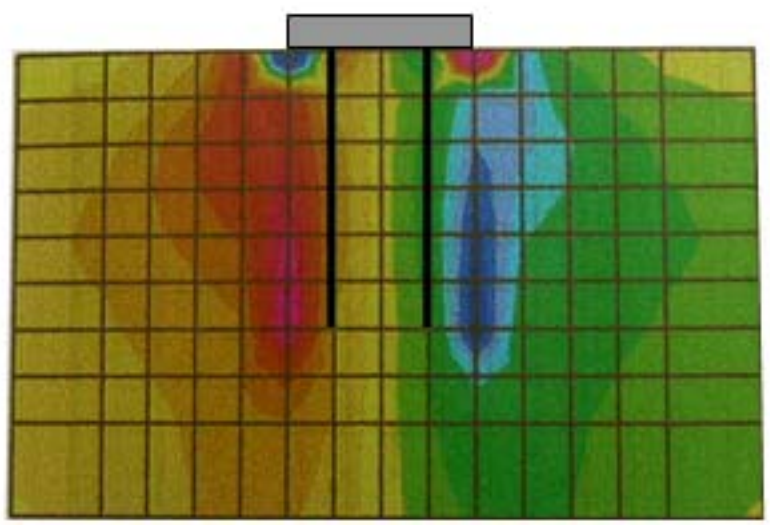

Figure 7. Shear Stress For The Raft-Pile 


\section{CONCLUTIONS}

The contribution of raft transferring superstructure load to the soil is conventionally ignored. However for raft-pile foundations on soft to very soft soils, ignoring the raft contribution to the foundation-soil interaction is practically extravagant. In fact that the raft can give the contribution up to 30 percent of the system support, the value is principally important. Since using classic formula of the group efficiency with the maximum value is $100 \%$ rarely happen, the effect of the raft to the foundation system can not be simply discarded. Based on the numerical simulation, the raft contribution transferring the load to the underneath soil in raft-pile system can clearly be shown in terms of stress diagrams. In terms of displacement, the raft pile showed smallest value than the displacements of pile group and the single raft.

\section{ACKNOWLEDGEMENT}

A great thanks is offered to Zahratul Husni who has given important contribution in this work.

\section{REFERENCES}

Bowles, J. E., (1988), “Foundation Analysis and Design, McGraw-Hill Book Company”, Singapore.

Das, B. M., (1990), "Principles of Foundation Engineering”, PWS-KENT Publishing Company, Boston.

Davis, E.H. and Poulos, H.G., (1972), "The Analysis of Pile-Raft Systems, Aust. Geomechanics Journal”, Vol. G2, no.1, pp 21-27

Hakam, A., Darjanto, H and Soepriono, Dj., (2004), "Floating Raft-Pile in Soft Clay", Jurnal Teknik Sipil, Univ. Tarumanegara, No.3, Tahun ke-X, pp 249-262.

Hakam, A., Novrial, Pane, I F., (2005), "Load Capacity of Floating Raft-Pile”, Atrium, Universitas Sumatera Utara, Vol. 02, No.1, pp 5-14.

Valliappan, S., Tandjiria, V. and Khalili, N. , (1999), "Design of Raft-pile Foundation Using Combined Optimization and Finite Element Approach”, International Journal for Numerical and Analytical Methods in Geomechanics, Vol. 23, pp 1043-1065. 
Floating Raft-Pile Foundation Analysis Using Numerical Simulation

46 | J URNAL REKAYASA SIPIL 